\title{
Sare sozialen analisia erakundeetan: auzo-elkarte sareen azterketa
}

Analysis of social network in organizations:

Study of neighborhood-associations networks

Ángel Belzunegui • angel.belzunegui@urv.cat

UNIVERSIDAT ROVIRA I VIRGILI, GIZARTERATZE KATEDRA

David Dueñas・david.duenas@ttu.ee

TALLINN-EKO UNIBERTSITATE TEKNOLOGIKOA, BERRIKUNTZA

ETA GOBERNANTZA SAILA, ESTONIA

Eguzki Urteaga • eguzki.urteaga@ehu.eus

UNIVERSIDAD DEL PAÍS VASCO-EUSKAL HERRIKO UNIBERTSITATEA, SOZIOLOGIA ETA GIZARTE LANGINTZA SAILA

Recibido: $11 / 05 / 2017$

Aceptado: 15/06/2018

\section{Laburpena}

Artikulu honek sare sozialen analisia (SSA) erakundeei aplikatzea proposatzen du kasu bat aztertuz. Lehenik, sareen analisia erakundeen testuinguruan aplikatzeko proposamen teoriko-praktiko aurkeztuko da, ondoren, Tarragona hiriko auzo-elkarteen sarea jorratzeko. Proposamen honek erakutsi nahi du zein izan daiteken sareen analisiaren interesa erakundetze fenomenoak ulertzeko. SSAk modelo analitiko meso-soziologiko bat proposatzen du non egitura eta erakunde-barruko harremanak jorratzen diren. Hori dela eta, erakunde bakoitzaren ezaugarri propioei, harreman-sarean betetzen duen kokapena gehitu behar zaio. SSAk, erakundeen arteko harremanen ulermenean sakontzea ahalbidetzen du egiturazko informazioa emanez. Azalpen teorikoa sendotzeko, kasu praktiko bat aztertuko da, alegia, Tarragonako auzo-elkarteen arteko barne eta kanpo harremanak. Kasu zehatz honetan, auzo-elkarteen borondatea eragin politikoa edukitzeko sare sozialen analisiaren aplikapenerako funtsezkoa bilakatzen da, zeren egitura mailaren azalpen gaitasunak informazio gehigarria ematen du ulertzeko nola elkarte horiek erakunde bezala dabiltzan, beraien jarrera, ekintza eta helburuetan eragina edukiz.

Hitz gakoak: Sare sozialak - erakundeak - auzo-elkarteak - Tarragona.

\section{Abstract}

This text presents a theoretical and practical proposal application of the networks analysis in the organizational context and, subsequently, a case analysis of the neighborhood association network of the city of Tarragona (Catalonia). The theoretical proposal aims to analyse the potential of social networks analysis in relation to understanding the functioning of social organizations. The network analysis raises a meso-sociological analytical model that permit to study the structural and inter-organizational relations. So, to the specific attributes of each organization, is added its position in the relations network that configures or in which it participates, providing a structural information that allows to deepen the comprehension of the relationships between organizations. To reinforce the theoretical explanation, this article includes a practical approach of case analysis of the neighborhood association network of the city of Tarragona, considering how intertwine the internal and relational elements of these organizations. In this specific case, the will of political impact of neighborhood organizations converts them in relevant actors in the application of network analysis, because the explanatory power of the structural level adds a crucial information to understand the way in which these entities works as organizations, influencing their attitudes, actions and objectives.

Key words: Social networks - organizations - associations - Tarragona. 


\section{SARRERA}

Sare sozialen analisiak (SSA), proposamen teoriko-metodologiko bat ordezkatzen du zeinek harremanen eta egituren analisia ohizko hurbilketa kuantitatibo ala kualitatiboei uztartzen dion, hala nola, soziologian, antropologian, psikologia sozialean ala epistemologian, diziplina batzuk aipatze aldera. Onartzen badugu gizakia animali sozial bat dela eta, teoria soziologikoak planteatzen duen bezala, eragile sozialen asmatze zein eraldatze prozesuen funtsean pertsonen arteko hartu-emana dagoela, errealitatearen analisi soziologikoa, ahal den neurrian behintzat, osagai berriak sartzen saiatu behar da, hartu-eman horiek eta beraien ondorioak ulertzeko asmoz. Testu honetan, ikuspegi hau, SSA alegia, erakundeen azterketara aplikatzen ahaleginduko gara bere oinarri teorikoak azalduz eta adibide zehatz baten bidez irudikatuz, alegia, Kataluniako hiri ertain (Tarragona) bateko auzo-elkarteen harreman sare bat jorratuz.

Sareen analisia erakundeen eremura eramateko helburuak, erakunde zehatz baten (ala erakunde multzo baten) harreman-egitura deskribatzea suposatzen du, esan nahi baita sistema sozial konkretu baten harreman-egitura jorratzea. Lehenik eta behin, eragileak identifikatzea ezinbestekoa da, ondoren, horien artean sortzen diren hartu-emanak ezagutzeko. Harreman horietatik irteten den diagramak, erakunde barruko ala erakundeen arteko sarearen itxura eta dentsitatearen intuiziozko ezagutza bat eskaintzen digu. Eragileek sare horren baitan daukaten kokapenak esaten digu «estrukturalki baliokideak diren eragileen» artean dagoen zatiketa maila; horrek sarearen baitan dagoen hierarkia agerian uzten duelarik. Sareen analisia ala egiturazko analisia tresna eraginkor bat da erakundeen azterketan perspektiba berriak irekitzeko eta erabilgarria izan daiteke, bai erakunde bateko barne egoera jorratzeko, bai erakundeen arteko loturak hausnartzeko; eta, bi kasuetan, problematika oso ezberdinetan. Kontutan izan behar da, gaur egun, aurkikuntza eta berrikuntza taldeen zein erakundeen ezaugarriak direla eta ez bakandutako gizabanakoenak. Uzzi-k (1996) dion bezala, aurrerapen handiak, lankidetza zirkuluen baitan egiten den lanetik datoz.

Artikulu honetan, sareen analisia erakunde baten barruko sare bati aplikatuko diogu, Kataluniako hiri ertain bateko auzo-elkarteek osatzen dutena alegia. Horretarako, zenbait kasutan, ezinbestekoa izango zaigu sarea osatzen duten erakundeen ezaugarri propioei erreferentzia egitea baita ere horien baitan dauden sareak aipatzea. Ikerketa honek Udalak ezagutzen dituen auzo-erakunde guztiak jorratuko ditu: 43 lurralde horretan. Kopuru horrek, erakunde guztiak aztertzeko aukera eskaini digu.

Konparatiboki, aztertzen dugun hiriak handitasun bereko beste hiri batzuk baino auzoelkarte kopuru handiagoa dauka (Dueñas-Cid, 2015). Hori jakinik, gure buruari galde diezaiokegu zergatik hainbeste auzo-elkarte dauden? Galdera horri erantzuteko ezinbestekoa da auzo-sarearen konfigurazioan erlazio dinamikek jokatzen duten papera aztertzea. Abiapuntu gisa, azpimarratu behar da auzo-elkarteen aniztasuna ez dagoela soilik hirietako egituren ezberdintasun posibleei elkartua ezta ere harreman sareen morfologiari 
lotua, baizik eta, baita ere botere harremanei; jakinik, maiz, hiriko harremanen mapan daukaten posizioei uztartua dagoela. Horrek ez du bat egiten, sarri, auzo-elkarteek plazaratzen dituzten diskurtsoekin.

Hipotesi honek bat egiten du Kahler-ek (2017) egindako proposamenarekin, zeinen arabera, egitura eta agentziaren arteko harremana berdefinitu beharra dagoen harreman alderdiak barnebilduz: sare batean kideek betetzen duten tokia, une berean, arrazoia eta ondorioa baita. Horrek, jarduera eta ekintza batzuk ulertzea ahalbidetzen du, baita ere, posizio horretara daramaten gertakizunen sekuentzia marraztea errazten du. Horren bitartez, sare ala ekintza-eremu estrategiko zehatz batean, boterearen kudeaketaren barne mekanismoen ulermena hobetzea faboratzen du (Fligstein, 2011). Ikerlan honetan frogatu nahi dugu egituren erreplika isomorfikoa ez dela arrazoia.

Modu horretan, artikuluaren ondorioetan adierazten den bezala, sare ezberdinetako egiturak oso antzekoak dira. Hori dela eta, komenigarria iruditu zaigu isomorfismo instituzionalaren teoriatik irakurketa bat egitea, esan nahi baita auzo-elkarteak eta beren harreman-egiturak aztertzea egitura horien homogeneizazio prozesuen emaitza gisa; kontziente izanik egitura horiek antzeko presioak jasaten dituztela ingurugiro instituzional ezagatik.

\section{METODOLOGIA}

Ikerketa hau burutzeko, honako metodoak erabili ditugu: 1) Tarragonako Elkarte Erakundeen Inkestatik datozen datuak (Belzunegui, Dueñas, Maza eta Pujadas, 2010), jakinik Tarragona hiriko elkarteen funtzionamenduaren deskribapenean erdiratzen direla; 2) hiriko auzo-elkarteetako zuzendaritzetako kideekin egindako erdi-egituratutako 40 elkarrizketak; eta, 3) erlazio alderdietan zentratzen den galdetegi bat.

Planteamendu metodologiko honek ahalbidetu du informazio esanguratsua biltzea hiru eremu nagusitan: erakundeen ezaugarriak; hiriko gainontzeko erakundeekin mantentzen dituzten harremanak; eta, hainbat gaien inguruan dituzten pertzepzioak, hala nola, harreman eta mobilizazio sozialak, instituzioekin eta auzoan ordezkaritza daukaten beste erakundeekin dituzten hartu-emanak.

Datuen analisirako, Atlas.ti (analisi kualitatiboa), SPSS (analisi kuantitatiboa) eta Gephi (sareen analisia) erabili dira. Lan honek, Belzunegui, Brunet eta Pastor-ek (2012) maila askotako datuen analisirako proposatutako modeloa jarraitzen du, datu kualitatibo eta kuantitatiboen integrazio analitikoa errazten baitu. 


\section{SAREAK, ISOMORFISMOA ETA ERAKUNDE ANIZTASUNA}

Sareen analisiak erakunde-barruko sistemen alderdi askoren ulermena erraztu du (Powell eta Oberg, 2017), besteak beste, erakunde bakoitzeko kideen arteko gizarte kapitalaren banaketa ezberdina (Agneessens eta Wittek, 2012), harreman informalak eta jokatzen duten papera egitura formaletan (Barker, 1992; Brass, 1992; Lazega, 1992b), informazioaren transmisio forma ezberdinak eta bere filtrazioa (Monge eta Eisenberg, 1987), baliabideen trukaketa (Stevenson, 1990; Stevenson eta Gilly, 1991), laguntza-harremanen analisia erakundeko kideak errekrutatzeko (Burt eta Ronchi, 1990; Weesie eta Flap, 1990), erakundeko gizon eta emakumeen arteko ezberdintasunak berrindartzeko harreman mekanismoak (Ibarra, 1992; 1993) ala ezberdintasun sozialak eta ezberdintasun ikusezinak erakundearen baitan (Kearns, Suri eta Monfort, 2003), ezberdintasun sozialak eta sareen inpaktuak mikro-kredituetan (Christakis eta Fowler, 2010), kutsatze jarrerak merkatuan (Nelly eta O'Grada, 2000), boterearekiko erresistentzia sareetan programatuak (Arquilla eta Rondfeldt, 2001), ala bozka jarrerak hauteskundeetan (Beck, 2002), tokiko erakundeen sare erantzuna korporazio sare multinazionalen aurrean (Juris, 2008), sareen egitura hezkuntza ingurugiroan (Lubbers, 2003; Lubbers eta Snijders, 2007), harreman eta sareak migrazio komunitateetan (Vermeij, Van Duijn eta Baerveldt, 2008).

Jorratutako beste eremu bat, erakunde barruko harreman eta egitura ekonomikoena izan da. Alor honetan, erakundeen arteko kapital, pertsona eta informazio trukaketak aztertu dira (Aldrich eta Marsden, 1988), baita ere trukaketek, menpekotasunak eta botereak mantentzen duten harremana, trukaketa ez-ekonomikoen kasuan lez (Stokman, Ziegler eta Scott, 1985), lankidetza zientifikoaren sareak eta lankidetza horren eraginkortasuna (Uzzi eta Spiro, 2005), erakundeen arteko sareen eragina politika publikoen definizioan (Stokman eta Van den Bos, 1992), erabaki-hartzea nazioarte mailan (Stokman eta Van Oosten, 1994), erakundeen biziraupena, negozio sareetako harremanen egitura informalean betetzen duen posizioaren arabera (Burt eta Talmud, 1993), sareen analisia eta jarduera estrategikoa baita ere aliantza estrategikoen sorrera (Barley, Freeman eta Hybels, 1992), sareak eta ekintza kolektiboa (Flores, Koster, Lindler eta Molina, 2012).

Sarreran esan dugun bezala, DiMaggio eta Powell-en (1991) teoria instituzionalistaren alderdi batzuk erabiliko ditugu eta, bereziki, isomorfismo estrukturalaren analisiari loturikoak, beti ere erakundeen arteko egituretan ikusten diren antzekotasunak azaltze aldera. Isomorfismo instituzionalak, partekatutako kultura-sistemei erreferentzia egiten die, suertatu daitezken homogeneizazio prozesuak ulertzeko, baita ere isomorfismo lehiakorrari (erakundeen egokitzapena merkatuan gertatzen diren aldaketen aurrean, lehiaren bitartez) ala lehia hainbat faktoreren ondorioz, hala nola, eragin politikoa, legitimitatea, pertsonen ala talde txikien nahiak, eta abar. Erakundeei buruzko literaturan, bigarren isomorfismo motaren bi garapen mota aurreikusten dira: batetik, erakunde handiek gizarteari begira derrigortzen dituen jarraibideak, prozedurak zein egiturak (Brunet, Belzunegui eta Pastor, 2011), eta; bestetik, lankide hurbilenei in- 
posatzen zaizkien parametro berberak (enpresa hornitzaileen kasuan lez) (Meyer eta Rowan, 1991).

Aitzitik, gure ikuspuntutik, panorama hau garapen berri baten bidez osatzea komeni da, eragin politikoa eta instituzioek egiten dituzten baliabideen kudeaketa eta transferentziak landuz. Udaletxeak bezalako instituzioak diru-iturriak bilakatzen dira auzo-elkarteentzako, eragin politikoaren eta baliabideak kudeatzen eta banatzen diren prozeduren menpe daudelarik. Horrek, isomorfismoa eta egituren jarrerak zein erantzunak azal ditzake. Edozein kasutan, erakunde-egiturak bere ingurugiro instituzionalari erantzuten dio. Erakundeek beraien ingurugiroarekin dauzkaten hartu-emanek eragiten dute erakunde horiek modu zehatz batean egituratzea eta interakzio modua oso antzekoa edukitzea.

Erakunde eremu bat osatzen doan neurrian, erakunde berriek jadanik existitzen diren egitura zein jarrerak errepikatzeko joera daukate. Zehazkiago, aztertu ditugun auzo-elkarteetan, zilegitasuna bermatzen duten antolaketa eta egituraketa moduak ikusten dira, erakundeen homogeneotasuna faboratuz. Prozesu isomorfikoek erakundeei aitortza ematen diete, bai beste erakundeekiko bai instituzioekiko, eta ziurgabetasuna murrizten dute, funtzionamendu eta hartu-emanetan itxaron daitezken egiturak eta prozedurak errepikatuz. Auzo-elkarteen kasuan, modu espazialean irudikatuta, ziurgabetasunaren murrizketa bi ardatzen inguruan antolatzen da: finantzaketa eta erabaki publikoen gainean daukaten eragina. Powell eta DiMaggio (1991) jarraituz, isomorfismo mimetiko baten aurrean egongo ginateke, hots, erakundeen erantzun egokitu bat, egituren, antolaketa moduen, teknologia berrien ala berrikuntzaren errepikapenari dagokionez.

\section{SARE SOZIALAK ERAKUNDEETAN ETA ERAKUNDE SAREAK}

Sare sozialen analisiak (SSA) azterketa-gai gisa hartzen ditu gizabanako, talde ala erakunde baten inguruan sortzen diren sare sozialak, dauzkan harremanetatik habiatuz, sistema eta egitura sozialean betetzen duen tokian ekinez (Giner, 2002). Sare sozial bat, Mitchell-en (1969) definizio klasikoari jarraituz, eragile ala nodo multzo batean gertatzen diren harremanak gisa ulertu daiteke, jakinik lotura horiek definitzen dituen ezaugarriak eragile horien jarrerak ulertzeko erabili daitezkeela. Zentzu horretan, SSAk bihurgune bat suposatzen du analisi soziologikoan, harremanen boterean erdiratuz, gizabanakoaren ezagutzan eta gizabanakoen arteko elkarmenpekotasunak bizitza sozialaren konfigurazioan duen garrantzia onartuz. Batze soziala eta jarreren transmisioa, sare sozialen barruan elkar elikatzen diren prozesuak dira. Erakundeetako sare sozialen kasuan, bere inguruan egon daitezken lotura ahulak dituzten eta erakundean nagusiak diren jarrerak imitatzeko joera duten pertsonak, baina sare hori beste sareekin lotzen dituzten pertsonak ere izan daitezke, lotura lana eginez (Belzunegui, Dueñas, Maza eta Pujadas, 2010). 
Ildo berari jarraituz, Molina-k (2001) bost arrazoi aurreratzen ditu esateko gizabanakoa zeharkatzen duen egitura sozialaren ezagutzak errealitate sozialaren ulermena hobetzen duela:

- Egitura sozialek balore azaltzaile handiagoa dute sistema osatzen duten kideen ezaugarri indibidualak baino. Ohizko ikuspegi kualitatibo eta kuantitatiboek datu kopuru anitza eskaintzen dute eragile sozialaren funtzionamendu indibiduala ulertzeko baita ere bere ezaugarriak partekatzen dituen eragileen funtzionamendu erak eragiteko, emaitzak orokortzearen bitartez. SSAk, bere aldetik, ibilmolde indibidualaren kanpoko analisi bat eskaintzen du, aurreko datuei, gizabanakoa kokatzen den sare sozialari buruzko informazioa eta eragileen arteko interakzioen inguruko azalpenak proposatuz.

- Ibilmolde jarraibideak, pertsonak harreman egituran betetzen duen tokiaren arabera agertzen dira. Sare baten ibilmoldearen ulermena ez da osoa, osatzen duten nodoen arteko harremanen funtzionatzeko era ez bada planteatzen. Nodo berezi baten funtzionamendu-osagai batzuk ulertu daitezke (ala ezaugarri antzekoak partekatzen dituzten eragile ala nodoak) bere barne ezaugarrietatik habiatuz, baina ezin daiteke sarearen ulermen orokorra planteatu, ezta ere nodo/eragile baten proiekzioa sare baten gainean, gizabanakoa gainditzen duen informazioa eduki gabe. Horrela, nodo ala eragileen jardueren ulermenera daramaten osagai asko ez dira osagai indibidualetan aurkitzen, osagai kolektiboetan baizik.

- Egitura sozialek harremanen ibilmoldea erabakitzen dute. Sare sozialean betetako tokiek boterearen rol zein lekuen sorrera eta mantenua ahalbidetzen dute. Azkenean, garrantzia edukitzen amaitzen dute, esaterako, eragile batzuekin eta ez besteekin dauzkaten harreman berrien sorreran. Horrela, eragilearen jarreraren ulermena, eragile ezberdinek mantentzen dituzten harremanetan oinarritzen da.

- Gizartea sare sozialez osaturik dago, ez talde sozialez. Egitura soziala osatzen da sare sozial baten izaeratik abiatuz, zeinek gizartea osatzen duten osagai zenbait batzen dituen, talde eta barne sareak sortuz, interes, botere ala baliabide batzuk lortzeko aukeren arabera. Gizartea sare bat bezala ibiltzeak, eragile batzuei aukera ematen die, beraien ezaugarrien arabera, talde batzuetara iristeko. Baina, ez direnez talde itxiak, berau osatzen duten kideek ez daukate esklusiboak zaizkien ezaugarririk. Hori dela eta, sare batean sartzearen arrazoia sare sozialaren ibilmoldean bilatu behar da eta ez taldean berean, beste nodo ala eragileekin harremanak mantentzeak bere biziko garrantzia duelarik. Gauzak horrela, harremanen egituran aurrera egiteak gizartearen ezagutzan aurrera egitea suposatzen du.

- Harreman metodoek analisi indibidualak osatzen dituzte. SSAk sarea osatzen duten nodoen funtzionamendu osoa ulertzeko aukera eskaintzen du, hori dela eta, bidea irekitzen du eragileen analisi indibidual batek ulergaitzak bilakatuko lukeen osagai batzuk ulertzeko. SSAren bidez lortutako datuek, eragile bakoitzari buruzko datuak osatzen dituzte eta sare osoari baita ere sareen arteko harremanei esanahia ematen die. Azpimarratu behar da, bestalde, eragileek sarean betetzen duten tokia ez dela azarosoa baizik eta pertsona bakoitzak eremu bakoitzean (politika, ekonomia, kultura) egiten duenaren eta daukan zentraltasunaren araberakoa dela, baita ere dauzkan baliabide zein 
aukeren araberakoa dela. Sare batean toki zehatz bat betetzeak, baliabide, informazio eta aukera batzuei iristeko aukera eskaintzen du, baina beste baliabide batzuetara ailegatzeko mugak zein oztopok eragiten ditu, Putnam-ek planteatutako gizarte kapitalaren ideiari zentzua emanez (Putnam, 1995; Urteaga, 2013).

Horrela, SSAk eremu meso-soziologikoan analisi modelo berri bat proposatzen du, harreman estruktural ala makro-sozialaren eta kokapen indibidual zein mikro-sozialen artean loturak eginez, gizabanakoen artean suertatzen diren harremanetatik abiatuz eta gizarte zientzietan nagusi den mikro-makro ohizko bikotea gainditzeko aukera eskainiz. Ikuspegi teoriko honek egitura sozialaren irudia hausten du, analisi soziologikoari sakontasuna ematen dion azalpen eta azterketa boterea eskainiz.

Erakundeak, beti ere ulertuta denboran eta espazioan jarduerak egituratzen, sailkatzen eta banatzen dituzten giza-ekintzen eraginak lez eta bete nahi dituzten helburuen arabera arau multzo batzuk dauzkatenak bezala (Brunet, Belzunegui eta Pastor, 2011), SSAren bidez aztertu daitezkeen osagaiak dira. Erakunde mailan, bi maila analitiko bereiztea komeni da, beti ere erakundearen ulermenera norabidetuta, gizabanakoa eragile bat bezala ikusten denaren arabera (sareen analisia erakundeen barrura norabidetuz) ala erakundea eragile bat gisa ikusten denaren arabera (erakundeak beste sareekin dauzkan harremanak aztertuz).

Orokorki, SSAk bere arreta komunikazio prozesuetan eta informazio jarioetan jartzen du. Sare sozialen funtzionamendu logikak leku garrantzitsuetan kokatzen diren nodo batzuk hobesten ditu, kontaktu asko ala garrantzitsuak dituztelako. Zentzu horretan, Granovetterek (1973) dio, bi ala nodo gehiagoren artean dagoen harremana handiagoa denean, horiek joera daukatela gero eta antzekotasun handiagoa edukitzeko. Horrenbestez, harreman sendoek balio dute sarearen eragileak homofilizatzeko.

Ospetsua bilakatu den artikulu horretan, Granovetter-ek (1973), Haider (1958) eta Newcomb-en (1961) balantze kognitiboaren teoria aipatzen du, zeinek dion «nire lagunen lagunak, nire lagunak direla». Zentzu horretan, Christakis eta Fowler-ek (2010: 178-179) diote «talde sozial ezberdinek adostasuna lortzeko duten azkartasuna sarearen egiturari lotua dagoela. Sareetan non pertsona batzuek besteek baino bizilagun gehiago dituzten, bizilagun gehiago dituztenek sinestarazte-botere handiagoa beharko dute, «gutxiengoaren boterearen eragina» deitzen zaiona. Eragin lekuetan kokatuta dauden gizabanako gutxi batzuk beraien helburuak lortu ditzakete nahi duten aldi oro. Halaber, talde batek batasun orokorra erraztu dezake baita ere denek galtzea galarazi. Horiek hola, sare sozialek lagundu badezakete gizabanako batek bakarrik egin ezin dezakeena egiten, ongi konektatutako pertsona batzuei boterea eman diezaieke. Izan ere, lotura gehien dituzten pertsonek maiz onura handiagoak jasotzen dituzte.

Granovetter-en (1973) argudioa, informazioaren eta komunikazioaren zirkulazioari dagokionez, harreman sozialetan lotura ahulek daukaten garrantzian erdiratzen da, zeren lo- 
tura indartsuek homofiliara daramate. Bestela esanda, lotura ahulek informazio berria transmititzeko eta eskuratzeko balio dute. Beraz, sare sozialen ibilmolde logikak ez ditu lotura sendoak saritzen baizik eta lotura ahul anitzak bezain ezberdinak, eta, lotura horiek dauzkaten pertsonek, zentraltasun bat lortzen dute sare sozialean eta bertan paper garrantzitsu bat jokatzen dute. Ildo berari jarraituz, azken urteetan ikerketak biderkatu dira sare sozialen ondorio ezkorrak azpimarratzeko (Labianca, 1998; Takács, 2008). Esaterako, aztertu nahi dute zein ondorio dauzkan sare sozial baten gainean osatzen duten nodoen arteko harreman ezkorrek, balantze kognitiboaren teoriaren aurkako tesia defendatuz, alegia: «nire etsaien lagunak, nire etsaiak dira». Lotura ahulei beraien garrantzia kendu gabe, erakusten dute sare horiek informazio ezkorra hedatu dezaketela eta gatazkak sortzen dituztela. Castells-ek (2009) ere azpimarratzen du boterea pertsona batek beste bati bere jarrera derrigortzeko harreman gaitasuna dela eta bi oinarrizko mekanismoren bidez gauzatzen dela: sareak sortzeko eta eraldatzeko gaitasuna, sareak finkatzen dituen helburuetatik habiatuz, eta sare ezberdinak lotzeko eta beraien arteko lankidetza bermatzeko gaitasuna.

Blasche eta bere lankideek (2012) oso sailkapen argigarria planteatzen dute SSA erakundeei aplikatzeari dagokionez. Bertan, SSAren esperientzia ezberdinak hiru taldetan banatzen dituzte sarean daukaten zentraltasunaren arabera:

— Gizabanako sareak: erakundeetako barne analisia burutzea, erakundeen barruan informazioa eta komunikazioa zirkularazten duten gizabanakoen harreman-sareak izendatuz. Gizabanakoak nodoetan kokatu behar dira, horien arteko harreman ala harremanezak sareari itxura eman diezaion eta aukera eman dezan jakiteko zein pertsonek paper garrantzitsu bezain zentralak betetzen dituzten. Planteamendu honen isla Csaba eta Pál-en (2010) lanean aurki genezake, non harreman ezkorren sortze eta eraldatze prozesuak aztertzen diren hezkuntza testuinguruan dauden harreman sozial indibidualetatik habiatuz.

— Gizabanako sareak eta eragile ez gizatiarrak: eragile ez gizatiarrak harreman sareetan ez sartzea, erakundetik kanpoko azterketa erraztuz. Nahiz eta SSAren erabilerako giza eragileak eta eragile ez gizatiarrak modu berean tratatu daitezken sareko eragile gisa, ikuspegi honek analisiaren sakontasun handiagoa eskatzen du eragile ez gizatiarrak definitzerako orduan. Belzunegui eta bere lankideek (2010) antzeko ikuspegi bat erabili dute Tarragona hiriko elkarte-sarea aztertzerakoan.

- Kontzeptu sareak: ikuspegi honek komunikazioa bere analisiaren erdian kokatzen du, kontzeptuak sarearen nodoan kokatuz eta harremanak gizabanakoetan bilakatuz. Beraien erabilpenaren bidez ala kontzeptuen ezagutzaren bitartez, elkarren artean lotuak daude. Kontzeptu sareak oso baliagarriak dira erakunde barruko komunikazioarekin eta zentzuaren eraikuntzarekin lotuta dauden eremuak aztertzeko, Oliver eta Montgomeryren (2005) emaitzek erakusten duten bezala lanbideen mugen sorrerari dagokionez.

Halaber, erakundeen azterketari aplikatutako sareen analisia, bere kideen artean harremanak nola ekoizten eta berrekoizten diren jorratzen ahalegintzen da baita kide horien 
elkarmenpekotasun maila zehazten ere. Printzipioz, planteatu genezaken hipotesi logiko bat izango litzateke, sareak geroz eta dentsitate handiagoa edukitzean, orduan eta elkarmenpekotasun handiagoa legokeela bere kideen artean. Hala ere, dentsitate hori heterodeterminatutako dentsifikazio prozesuen ondorioa ere izan daiteke. Kasu honetan, elkarmenpekotasunak soilik formalak izan daitezke eta ez litzateke lan egoera zehatz bati lotua izango. Eragileek ez lukete ia egituraren eraikuntzan parte hartuko baizik eta egitura emana izango litzaieke.

Erakunde sareen analisia hiru prozeduretan erdiratuko litzateke. 1) Sarearen morfologiaren berreraikuntza, eragileen arteko harremanak deskribatuz. Erakundearen ikuspegi honek ez du maila indibiduala deuseztatzen baizik eta gizabanako eta egitura mailen artean feedback bat ahalbidetzen du. 2) Egituran gizabanakoek betetzen duten tokiaren azterketa. Analisi horrek bi osagai dauzka: batetik, eragileak erakundearen barruan daukan zentraltasuna ala ez deskribatzen duen dimentsio kualitatiboa, lortu den informazio gehigarriaren bidez, eta, bestetik, osagai kuantitatibo bat zeinek, neurri indibidualen bitartez, egiturako eragileen zentraltasuna, bazterketa, dentsitatea eta harremanak neurtzen dituen. 3) Eragileen arteko harremanen egituraren analisia eta beste egitura posibleen simulazioa eragile batzuen bitartekaritza-ezaren aurrean.

Hirugarren prozedura honetatik ondorioztatu daiteke eragile kopuru handi batek ez duela harreman profil bakarra baizik eta aldakorra dela egituraren baitan eta bere inguruan suertatzen diren aldaketen arabera. Hortik dator sareen analisian funtsezkoa den oinarria, alegia, sareen dinamismoak eta osatzen duten egiturak, ekintza sozialaren dinamismoa erakusten duela.

Erakundeei aplikatzen zaien SSAn garrantzitsua den kontzeptua rolarena da. Sarearen baitan betetzen den tokia adierazteaz gain, rol kontzeptuak pertsonek sare ezberdinetan betetzen dituzten posizioen emaitza agerian jartzen du (Lazega, 1994). Zentzu honi dagokionez, Christakis eta Fowler-ek (2010: 169-171) diote rolen arteko loturek «talde baten eta bestearen arteko zubiak bezala jarduten dutela eta, beraz, funtsezko paper bat jokatzen dutela. Lotura indartsuek gizabanakoak batu ditzakete taldeen barruan, baina lotura ahulek taldeak batzen dituzte gainontzeko gizartearekin eta erabakigarriak dira onuren inguruko informazioak hedatzeko (...). Horren inplikazioetariko bat da lotura ahul asko dituzten pertsonei maiz aholkua eskatzen zaiela eta aukerak eskaintzen zaizkiela informazioren ala sarbidearen truke. Bestela esanda, taldeen arteko zubi-lana egiten duten pertsonek sarearen funtzionamendurako funtsezkoak izaten amaitu dezakete eta, ondorioz, aukera gehiago dauzkate ekonomikoki ala beste modu batera sarituak izateko». Horrek pentsarazi lezake, erakunde barruko analisian, erakundeen arteko loturen hazkundeak beraien jarrerak sinkronizatzeko aukera ematen diela. Horrek bat egingo luke DiMaggio eta Powell-en (1983) egitura isomorfirmoarekin.

Sareen analisiak boterearen neurria proposatzen du gizabanakoen harreman-sisteman betetzen duen tokiaren arabera. Ondorioz, boterea ez da ezaugarri indibidual bat bai- 
zik eta harreman-sistemaren ezaugarri bat non eragileak zentraltasun bat ala toki periferiko bat okupatzen duen eta zeinetatik autonomia edo menpekotasun maila bat ondorioztatu daiteken. Horrela ulertuta, boterea hobari kultural bat da zein baliabide eta aukeren banaketa iturrian gauzatzen den. Nodo baten kokapenak ere adierazten du pertsona batek zenbat ziurgabetasun kontrola dezaken. Lazega-rentzako (1994), funtsezko kontua da jakitea nola eta zein neurritan eragile zentralek gaitasuna daukaten beraien zentraltasuna boterean bilakatzen. Aitzitik, ez da funtsezko galdera bakarra baizik eta beste hainbaten artean kokatzen da; hala nola, egituraren itxura bera, harremanen katea eta informazio jarioa, jarrera kolektiboa ala erakundearen konpromiso kolektiboa. Azken zentzu honetan, esan dezakegu sarea kanpoko sare batzuekin are eta lotuagoa delarik, orduan eta aukera gehiago daudela erakundeak gizartearekin modu arduratsuan jokatu dezan. Sare oso endogamiko ala itxiek, jarduteko modu oso ezberdinak dauzkate ingurugiroarekiko.

Bestalde, sare baten baitan, lotura orokorreko ereduetan dauden ezberdintasun txikiek taldearen errendimenduan eragin itzela eduki dezakete. Zentzu horretan, baliagarria izan daiteke sareen baitan lotura esplizituak sortzea.

\section{ISOMORFISMO KASU BAT SARE SOZIALETAN}

Sarreran esan dugun bezala, SSAren aplikapen zehatz bat aurkeztuko dugu erakundeen analisian gizabanako eta gizabanakoak ez diren sareetan erdiratuz; helburua, Tarragonako hiriko auzo-elkarteak jorratzea delarik. Lan hau ikerketa zabalago baten zatia da non Tarragonako elkarte eta erakundeen funtzionamendua erradiografiatu den (Belzunegui, Dueñas, Maza eta Pujadas, 2010), dimentsio askotako galdeketa modelo bat osatuz eta non Tarragonako Udaletxean izena eman duten 544 erakundetatik 325ek erantzun duten. Auzo-elkarteen kasu zehatzean, 40 elkarte eta auzo-elkarteen 3 federaziori buruzko informazioa jaso da; SSA datu horien gainean oinarritu delarik. Analisi hori erakunde bakoitzaren erradiografiarekin osatu da ibilmolde-patroi komunak agerian uzteko asmoarekin, beti ere sare horretako kide izana azaldu nahiz. Azpimarratu behar da, aztertutako 43 erakundeez gain, elkarrizketatu ezinak izan ziren elkarteei buruzko informazioa jaso dela. Horregatik, aztertutako sarea osatzen duten erakundeen kopurua 46era igo da.

Lehenik eta behin, ikusi daiteke nola elkarte horiek osatzen duten sarea ez dela oso dentsoa, nodo zehatz batzuen inguruan hiru aglomerazio sortu direla kontutan izanik: hiriko hiru federazioak alegia, eta gutxi lotutako nodo batzuk banaketa gunetik aldenduak daudela. Irudi hori hiriko elkarte eta instituzioek azaldutakoarekin bat dator. Izan ere, eragileek diote elkarteak hiru taldetan banatuta daudela (federazio horien banaketak maiz oinarri politikoak dauzkalarik), horien arteko desadostasunak sortuz eta beraien arteko harremanak okertuz. Horren ondorioz, federazio horiek auzo-mugimenduaren bozeramaileak bilakatu dira, bai elkarteen arabera bai kanpoari begira, batik bat instituzioekiko eta komunikabideekiko harremanetan. 
1. grafikoa. Auzo-elkarteen arteko harremanak

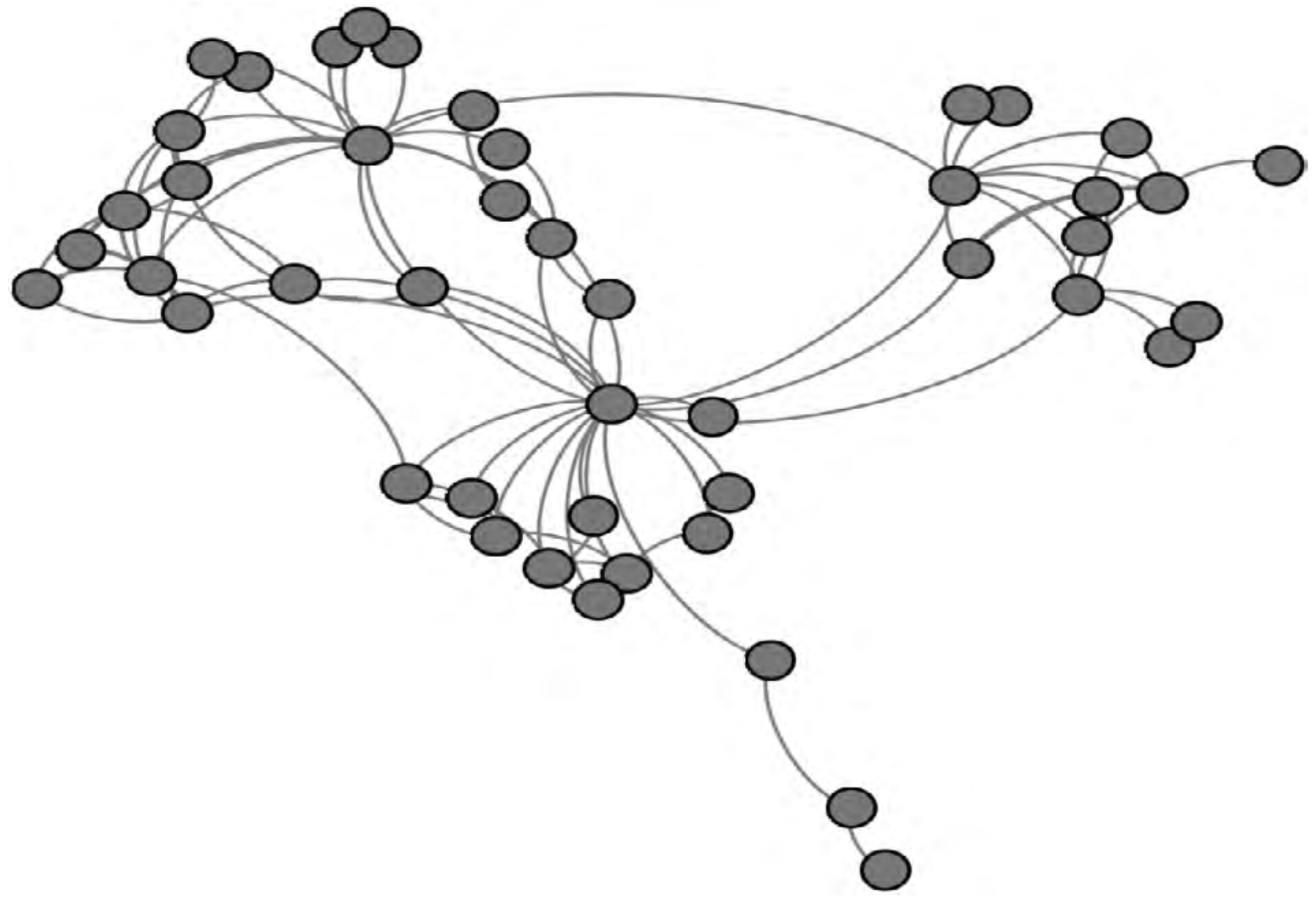

Iturria: norberak osatutakoa.

Auzo-elkarteen sarearen ikuspegia Granovetter-en (1973) ideiari lotua dago, alegia, lotura ahulek paper garrantzitsua jokatzen dutela informaziora eta baliabideetara iristeko orduan. Zentzu horretan, kontutan izan beharreko bi osagai daude: batetik, elkarteek joera daukate beraien antzekoak diren erakundeekin harremanak edukitzeko; hori dela eta, hurbiltasun handia dago antzeko baliabide, eremu sozial eta geografiko, kezka eta beharrak dituzten elkarteekin, eta, aldiz, urruntasuna da nagusi ezaugarri ezberdinak dituztenekin. Edozein kasutan, ezaugarri horrek ez du zertan auzo-elkarteen arteko urruntasunera eta hausturara eraman behar, batez ere lortzen badute auzo-mugimenduari propioa zaion barne negoziaketa ahalbidetzen duen interesen kudeaketarako sistema bat sortzea.

Kontutan izan beharreko bigarren osagaia elkarte horien sorrerari lotua dago, zeren hiriko auzo herrikoietako elkarteak lehenik sortu ziren. Izan ere, langile auzoetan elkarte horiek sortu ziren iragan den mendeko hirurogeigarren hamarkadan industrializazioak eragindako espainiar immigrazioari harrera egiteko. Aldiz, erdiguneko eta auzo aberatsetako auzo-elkarteak beranduago sortu ziren.

Galdeketen bidez ikusi ahal izan dugu nola elkarte berriek garatutako praktika gehienak oso antzekoak diren. Bestela esanda, ez dago ezberdintasun handirik elkarte horiek barne ibilmoldean eta bizilagunei eskaintzen dieten zerbitzuan. Datu hau kontuan har- 
tzekoa premiazkoa da antzekotasun estrukturalak irakurtzerako tenorean, isomorfismo instituzionalaren ikuspegitik. Halaber, hortik ondorioztatu daiteke interes ezberdinek (batik bat baliabideen lorpenarekin eta solasaldi politikoaren hegemoniarekin lotua) batasun federatiboaren modeloa zailtzen dutela. Testuinguru horretan, baliabideak eskuratzeko eta kontaktuak lortzeko auzo-mugimenduaren kontrolaren dinamika markatzen dute. Egoera hau, haustura errazten duen harreman eta praktika sistema baten oinarrian dago.

Lotura ahulen garrantzira itzuliz, federazio bakar baten kontrol posizioak eragiten du nodo bakar batek lotura politikoak eta beste eragileekiko harreman guztiak zentralizatu ditzakeela. Hori dela eta, nodo bakar batek mugimenduaren funtzionamenduan eragina eduki dezakeen lotura multzo bat dauka. Zentzu horretan, ez da harritzekoa, testuinguru horretan, elkarteak kudeatzen dituen interesak ez asetzea eta elkarte ezberdinak batzen dituen federazioak sortzea. Auzo-mugimenduko kideen artean dagoen lehia federazioak dakartzan baliabideen inguruan arrazoi nahikoa izan daiteke egitura paralelo eta isomorfikoen sorrera faboratzeko. Azpimarratu behar da hirian dauden auzo-federazio ezberdinak aurretik existitzen ziren zatiketetatik datozela, bigarren federazioa lehenaren zatiketatik datorrela eta hirugarren federazioa bigarrenarekin zatiketatik. Hori dela eta, lehen eta bigarren federazioen arteko harremanak hainbat kasutan hotzak bezain gatazkatsuak dira eta gauza bera gertatzen da bigarren eta hirugarren federazioen artean. Aldiz, lehen eta hirugarren federazioek harreman ona daukate nahiz eta ez maizkoa izan.

Lehen grafikoa (1. Grafikoa) egoera horren isla da non hiru nodo nagusiek, hiriko hiru federazioak alegia, sareari bere itxura ematen dioten. Sarea batzen dute federazio bakoitza osatzen duten kide bakoitza azpi-sare bateko kidea baita. Horrez gain, azpimarratu behar da elkarte batzuk federazioetatik kanpo daudela, nahiz eta sareko partaide izan, beraien harreman indibidualei esker eta federazioko ordezkariekin lotura zuzenik eduki gabe.

Datu horiek dauden harreman kopuruekin erlazionatzen baditugu (2. Grafikoa), erakundeen kolorearen handitasuna eta intentsitatea dauzkaten harremanen kopuruari lotua dagoela jakinik, ikusi daiteke nola bigarren federazioak harreman gehiago dauzkan (20), deialdi gaitasun handiagoa erakutsiz. Instituzio publikoen aurrean ezaugarri hori erabiltzen du bere garrantzia goraipatzeko eta aldarrikatzeko. Bestalde, federazio horri hurbilak zaizkion elkarteen harreman kopurua murritzagoa da, ordezkatzen dituzten federazioaren lidergoarekiko harreman piramidal bezain subsidiario bat agerian utziz. Lehen federazioak harreman gutxiago dauzka (17), hiriko elkarteen gainean eragin ahulagoa edukiz, nahiz eta osatzen duten elkarteek tamaina handiagoa izan eta beraien artean harremanak ukan. Azkenik, hirugarren federazioak harreman gutxiago dauzka (10), gainontzeko bi federazioak baino eragin mugatuagoa edukiz, nahiz eta behin eta berriro esan bere helburua ez dela hiri osoan eragina edukitzea baizik eta hiriko auzo batean (ekialdeko auzoan). Halaber, federazio horri hurbilak zaizkion elkarteek harreman asko dauzkate, bai federazio barruan bai federaziotik kanpo. 
2. grafikoa. Erakundeen harreman kopuruaren handitasun proportzionala (degree)

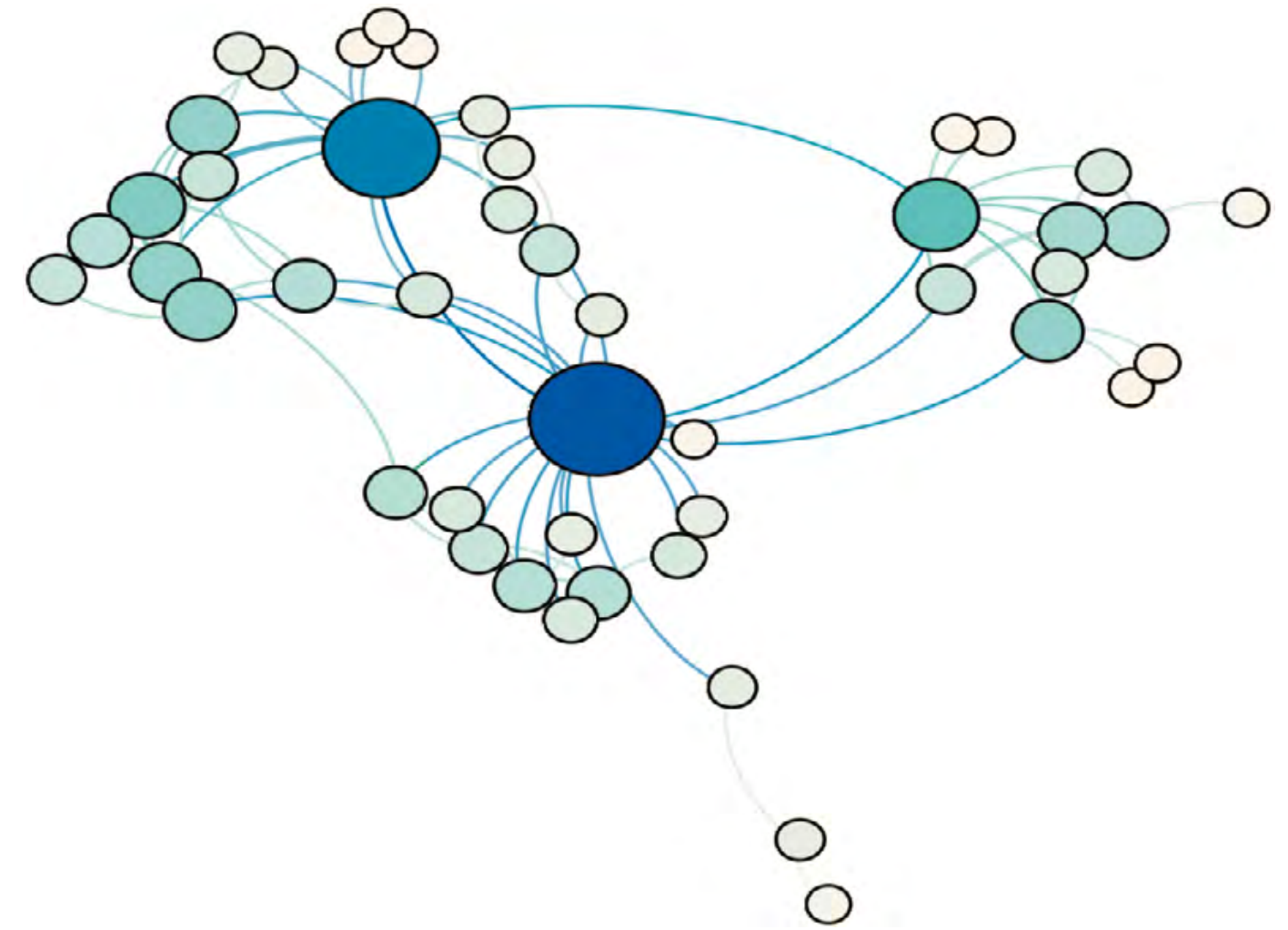

Iturria: norberak osatutakoa.

Sare osoan elkarteek daukaten eragina neurtzeko erabilitako bigarren adierazlea bitartekaritza maila da (betweenness), baliogarria baita nodo bakoitzak osotasunarekin daukan zentraltasuna neurtzeko. Adierazle horrek, sarearekin lotuta mantentzeko gainontzeko nodoek nodo batekin daukan menpekotasuna agerian uzten du, jakinik geroz eta nodo gehiagok sareari lotua izateko nodo baten beharra dutelarik orduan eta botere handiagoa duela. Zentzu horretan, nodoen handitasuna (3. Grafikoa) menpekotasun horri lotua dago, alegia, berarengandik igarotzea ezinbestekoa dela sareko kidea izateko eta beste erakundeekin harremanetan sartzeko.

Aurreko grafikoarekin gertatzen ez den bezala, non auzo-elkarte indibidualak garrantzi erlatibo bat zeukaten, elkarteen arteko harreman ugari zeuden neurrian, kasu honetan, bitartekaritzaren pisu osoa hiru federazioen gainean dago, gainontzeko erakundeek baino emaitza handiagoak edukiz.

Grafikoak aurretik esandakoa islatzen du federazioek jokatzen duten paperari dagokionez, ordezkaritza mailan eta gainontzeko erakundeekiko loturak sortzeko gaitasunean. Elkarteen artean harreman-sare integratu bezain kohesionatua ez edukitzeak, paper horri joka dezaketen erakundeei botere geroz eta handiagoa ematen die. Ikusi daiteken bezala, talde ezberdinen arteko harremanetan erakunde batek eduki dezaken rola hutsaren parekoa da, salbuespenak egon arren, auzo-mugimenduaren integrazio eginkizuna hiru federazioen esku utziz. 
3. grafikoa. Erakundeen bitartekaritza mailaren handitasun proportzionala

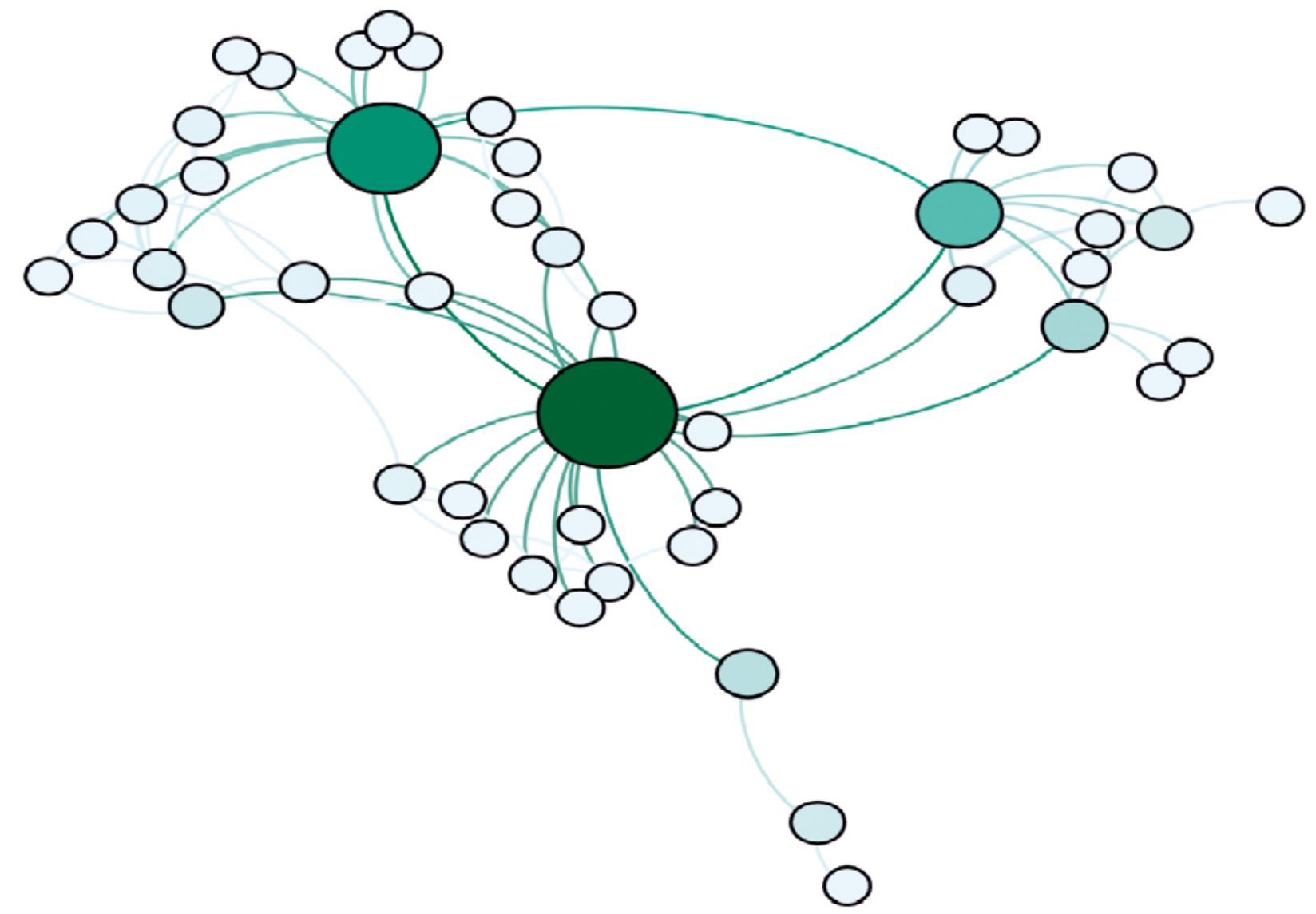

Iturria: norberak osatutakoa.

Alderdi hau garrantzitsua da zeren aukera eskaintzen du ikusteko nola hiriko elkarte-sareak egitura piramidala daukan, funtzioen banaketa ezberdina eraginez. Erakunde indibidualen esku dago herritar eta bizilagunekiko harremanak sortzea, integrazio orokorraren eginkizuna federazio ezberdinen esku dagoelarik. Horrek aukera ematen digu harreman gaitasuna eta kanpo harremanentzako borrokaren eztabaida berraztertzeko, zeren elkarteak ez daude lehian sare dentsoak osatzeko federazioak baizik. Zentzu horretan, federazioen eginkizun nagusietarikoa ez da hainbeste bizilagunen beharrak ordezkatzea eta defendatzea baizik eta elkarteen interesak babestea, baliabideak eskuratzeko lehia bat dagoelako.

Salbuespen bakarra federazio bakar bateko kideak ez diren elkarteetan aurkitu genezake zeren sare nagusiarekin lotura ahula daukate. Hori dela eta, ez daukate zentraltasunik sarean. Posizio hori betetzen duten zentraltasun fisiko eta politikoari lotuta dago. Horren ondorioz, ez daukate gainontzeko elkarteekin harremanak estutzeko ala federazioetan sartzeko beharrik baliabideak eskuratzeko eta harreman instituzionalak edukitzeko. Horregatik, beste elkarteekin mantentzen dituzten harremanak eta beraien bitartekaritza funtzioak ezberdinak dira.

Azkenik, nodoak hiriaren mapan geo-lokalizatzen baditugu (4. Grafikoa), ikusi daiteke nola hiriko elkarteen arteko zatiketen pean dauden gatazka politikoei buruzko diskurtsoa 
(argudio hori erabilia da federazio ezberdinen izaera zuritzeko) desegiten den. Horren ordez, lurralde logikak inposatzen dira harremanen banaketan.

4. grafikoa. Erakundeen banaketa hirian beraien bitartekaritza mailaren arabera

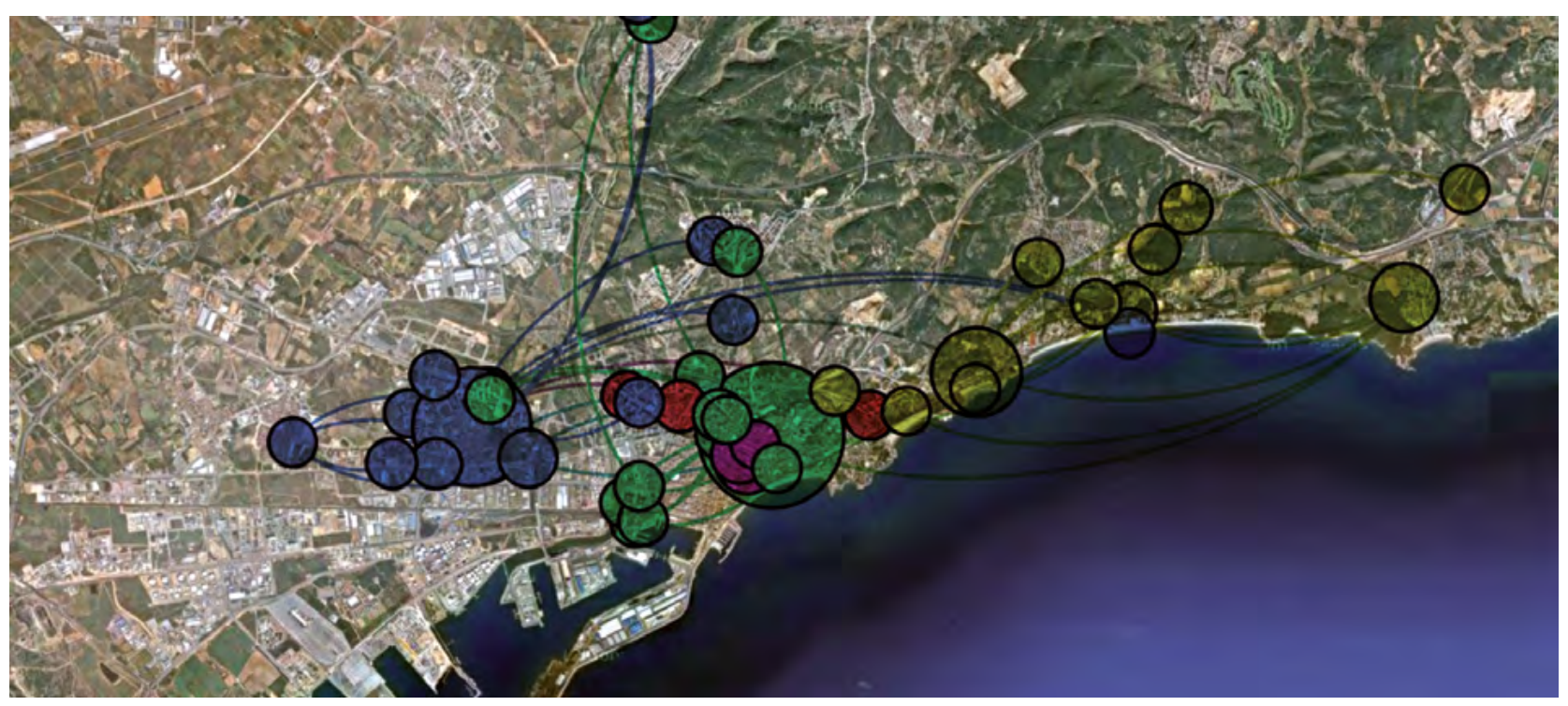

Iturria: norberak osatutako Google Maps1 maparen gainean.

Taldeak nodoen arteko harremanen arabera sortu ostean, laugarren grafikoak erakusten digu nola talde bati ala besteari loturiko erakundeen banaketak elkarteen banaketa ardatz politikoaren arabera egiten dela. Horrela, ikusi daiteke nola kokapen geografikoak funtsezko papera jokatzen duen endo-taldeen sorreran baita ere federazio modelo ezberdinetan. Lehen federazioak (urdinez), auzo herrikoiek osatzen duten mendebaldeko gunea okupatzen du baita iparraldeko gunea ere (antzeko ezaugarriak dituzten auzoak) eta nodo bakartu bat ekialdeko gunean. Bigarren federazioak (berdez), lehenaren zatiketa dena, erdigunea betetzen du baita iparraldeko gunearen nodo batzuk eta mendebaldeko nodo bat. Azkenik, hirugarren federazioak (horiz), modu argian ekialdeko gunea okupatzen du (federazio honek bere arreta eta ekintza gune horretara mugatzen duela jakinik).

Beraz, federazio horien eginkizuna lurralde eraginerako egituren sorrerarekin lotua dago, lurralde presiorako lobbying-a eginez, zeren banaketa oso lotua dago lurraldean betetzen den tokiarekin.

Halaber, interesagarria da ikustea nola gatazka garrantzitsuenak gertatzen diren federazio ezberdinak dauden tokietan, lurralde horiek dominatzeko eta ordezkatzeko lehia dagoelako (iparraldeko gunean federazioen arteko borroka dago, beraien arteko komunikazioa zailduz) ala lurralde hori ez dagoelako behar bezala ordezkatua gune horretako

${ }^{1}$ Google. Tarragona [Mapa Online Interactivo]. En: Google Maps, 2013 [41.117383, 1.244888] (Acceso febrero de 2013). 
gainontzeko elkarteekin alderatuta (bigarren federazioko nodo bakartuak mendebaldeko gunean eta lehen federazioko nodo bakartua ekialdean).

Deigarria da ikustea parte zaharreko elkarteak ez direla federazio bakar bateko kideak zeren hiriaren ohizko egitura politiko eta kulturalak garrantzi berezia dauka gune horretan. Hori dela eta, bertako elkarteek ez daukate federazio bateko kideak izateko beharrik beraien interesak defendatzeko eta beraien aldarrikapenak entzunarazteko, informazioa eta baliabideak lortzeko beste bide batzuk baitauzkate. Boterearen banaketa geografikoak hirian garrantzi berezia dauka laguntza-egituren sorreran zeren, hiriko zenbait gunetan beharrezkoa dena, beste batzuetan baliogabea eta antzua da. Horrek aukera ematen die federazioen artean egon daitezken gatazketatik kanpo gelditzeko baita ere sare nagusitik at geratzeko.

Azkenik, hiru elkarte daude (gorriz) zeinek, nahiz eta bigarren federazioko kide izan, ez daukaten ia harremanik gainontzeko elkarteekin.

Antzeko ideia bat agerian geratzen da federazioak mapatik kentzen baditugu (5. Grafikoa). Hiri mendebaldeko guneko erakundeek elkarren arteko lotura maila handiago daukate ekialdeko elkarteenarekin alderatuta eta, batik bat, erdiguneko elkarteekin konparatuta. Hori dela eta, gune horretako erakundeen artean pentsamolde eta ekintza batasun handiagoa dago, baita ere hiriguneetan loturak egiteko zailtasun handiago, non elkarte horien jarduerak ez daukan hainbeste garrantzirik bizilagunen eguneroko bizitzan.

5. Grafikoa. Elkarteen banaketa geo-lokalizatua harreman kopuruaren arabera

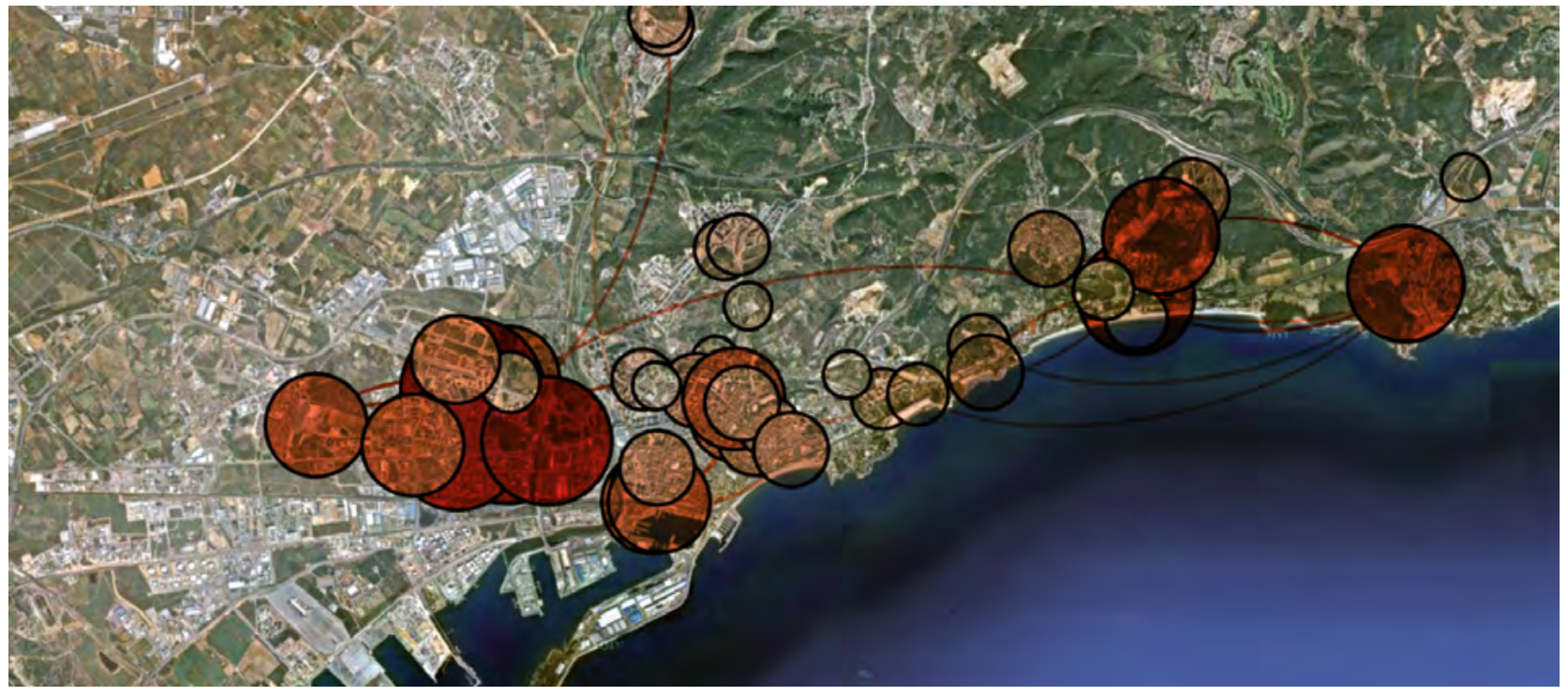

Iturria: norberak osatutako Google Maps maparen gainean.

Elkarte federazioen sorreraren oinarrian dagoen harreman-sareak errealitate ezberdinak islatzen ditu. Lehen federazioaren kasuan, zein auzo herrikoietako ohizko elkarteez 
osatua dagoen eta zeinek, bere garaian, hirian bere eragina eduki zuen, lotura sendo bat dauka mendebaldeko guneko elkarteen interesekin. Ezaugarri sozial eta egiturazko parekoak dituzten neurrian, federazioan gertatzen denaren inguruan eragin handia daukate.

Hirugarren federazioaren kasuan, non baliabide ekonomiko gehiagoko eta non bizi baldintzak hiriko beste auzoetakoak baino hobeak diren (erdigunetik urruti dauden etxebizitza familiabakarrak), eragin politikoa lortu nahi du lurralde lobbying-a praktikatuz eta hiri osoarekiko interes gutxi erakutsiz.

Bere aldetik, bigarren federazioaren egoera paradoxikoa da zeren bere muin-sortzaileak ez dauka ekintza komuna justifikatuko lukeen barne harreman esturik eta bere kokapen geografikoak ez dauka ezaugarri antzekorik zeinek ekintza-lerro jarraiki bat emango luken. Beraz, federazio honek auzo-mugimendu osoarengan eragile batzuek beraien gain hartu nahi duten lidergoari loturiko profil bat dauka. Horren ondorioz, menpekotasun politiko salaketak jasotzen ditu, nahiz eta gainontzeko federazioek alderdi politikoei afiliatuak dauden pertsonak eduki beraien arduradun karguetan eta jarduera politiko garrantzitsua eduki beraien ibilbide pertsonalean.

\section{ONDORIOAK}

Tarragona hiriko auzo-elkarteen analisiak ezberdintasun baino antzekotasun gehiago erakusten ditu beraien egitura, funtzionamendu eta harremanei dagokionez, batik bat bizilagunekin mantentzen dituztenekin. Hurbiltasunaren analisiari erreferentzia eginez (konglomeratuen analisia, kategoria eta eskala aldagaien sarrerarekin), azterketak ez ditu erakundeak argiki bereizten eta, ondorioz, ez ditu batzen barnetik homogeneoak eta kanpotik heterogeneoak diren taldeetan. Ohar hori egiaztatzen da federazio bakoitzaren baitan baita ere elkarte guztien kasuan. Analisiaren bigarren mailak hiru federazioen arteko ezberdintasunak agerian uzten ditu, beraien egitura, ibilmolde eta harremanei dagokionez. Kasu honetan ere ez da diferentzia nagusirik sumatzen. Anova bezalako bataz bestekoen alderaketa analisiek ez dute ezberdintasun estatistiko ezberdinak azpimarratzeko balio.

Hori dela eta, nola azaldu daiteke auzo-mugimenduaren zatiketa? Galdera horri erantzuteko ezinbestekoa izan zaigu azterketa kualitatibo bat burutzea zeinek erakundeen jatorri eta historiari baita ere instituzioekin mantendu dituzten harremanei garrantzi berezia eman dien.

Honako ondorioak atera daitezke:

—Erakunde sareen analisiak baieztatzen du harremen-egiturak oso antzekoak direla: elkarteak antzeko erakundeekin erlazionatzen dira eta instituzioekiko lotura federazioak bermatzen dute. 
- Pentsa genezake erakunde (ala federazio) baten sorrera hurbiltasun logikaren arabera dabilela eta auzoari propioak zaizkion problematiken konponketak motibatzen duela, baina horrek ezin lezake azaldu zergatik auzo berean ala eragin eremu berean hainbeste erakunde sortzen diren.

-Elkarte eta federazioen barne egiturak goitik datozen prozesu administratiboak dira, non legediak barne egituraketan eragin handia daukan. Ezaugarri honek erakundeen egituran zein funtzionamenduan eragin zuzena dauka.

-Elkarteen menpekotasun finantzarioak aurrekontuen kudeaketan antzeko prozedurak erabiltzera daramatza baita ere beraien jarduerentzako baliabideak banatzera.

—Erakundeek komunikazio modu antzekoak erabiltzen dituzte instituzioekiko harremanetan eta konplizitateak bilatzen dituzte beraien harreman informalen bidez.

- Bizilagunei zuzendutako erakundeek burutzen dituzten eginkizunak antzeko eredu bat jarraitzen dute baliabideak lortzeko eta legediak baldintzatzen dituzte.

Antzekotasun horiek, eragin politikoaren, lidergoaren eta baliabideak lortzeko beharraren ondorio zuzenak dira eta auzo-mugimenduaren zatiketaren oinarrian daude. Bestela esanda, zatiketa horrek ez luke arrazoi estrukturalik eta ez legoke bizilagunen arretari lotua, baizik eta alderdi politikoek burututako lurralde zatiketari eta instituzioen prozesu normatibo eta administratiboei itsatsia legoke. Izan ere, instituzioek solaskide bakar baten batasuna bultzatzeko ordez, elkarteen aniztasuna bultzatzen dute, eskaera zehatz bezain mugatuei erantzunez. Zentzu horretan, hainbat galdera sakontzea komeni litzateke urrengo ikerketetan: Nola gainjartzen dira azpimarratutako osagaiak auzo eremuan? Nola osagai horiek erakunde-egituren sorreran eta eraldaketan eragiten dute? Zein eragin daukate sareen konposizioan?

\section{ERREFERENTZIA BIBLIOGRAFIKOAK}

Agneessens, F. eta Wittek, R. (2012). Where do intra-organizational advice relations come from? The role of informal status and social capital in social exchange. Social Networks, vol. 34, n³, pp. 333-345. DOI: 10.1016/j.socnet.2011.04.002

Aldrich, H.E. eta Marsden, P.V. (1988). Environments and organizations. En Smelser, N.J. (eds.), Handbook of Sociology (pp.361-392). Beverly Hills: Sage.

Arquilla, J. eta Rondfeldt, D. (2001). Networks and Netwars, the Future of Terror, Crime and Militancy. Santa Monica: Rand Corporation.

Barley, S.R., Freeman, J. eta Hybels, R.C. (1992). Strategic alliances in commercial biotechnology. En Noria, N. eta Eccles, R. (eds.), Networks and organizations (311-347). Boston: Harvard University Press. 
Barrer, W.E. (1992). The network organization in theory and practice. En Noria, N. eta Eccles, R. (eds.), Networks and organizations (pp. 397-429). Cambridge: Harvard Business School Press.

Beck, P.A. (2002). The Social Calculus of Voting: Interpersonal, Media and Organizational Influences on Presidential Choices. American Political Science Review, n. ${ }^{\circ}$ 96, pp. 5774. DOI: https://doi.org/10.1017/S0003055402004239

Belzunegui, A., Dueñas, D., Maza, G. eta Pujadas, J.J. (2010). Associacionisme i Participació Ciudadana al municipi de Tarragona. Tarragona: Ajuntament de Tarragona.

Belzunegui, A., Brunet, I. eta Pastor, I. (2012). El diseño de Análisis Cualitativo Multinivel: una aplicación pràctica para el anàlisis de entrevistas. Empiria. Revista de Metodología de Ciencias Sociales, vol. 23, pp. 15-44. DOI: https://doi.org/10.5944/empiria.24.2012.841

Blasche, S., Schoeneborn, D. eta Seidl, D. (2012). Organizations as Networks of Communication Episodes: Turning the Network Perspective Inside Out. Organization Studies, vol. 33, n. ${ }^{\circ}$ 7, pp. 879-906. DOI: https://doi.org/10.1177/0170840612443459

Brass, D.J. (1992). Power in organizations: a social network perspective. En Moore, G. eta Whitt, H.A. (eds.), Research in politics and society (pp. 295-323). Tokio: Greenwich JAI Press.

Brunet, I., Belzunegui, A. eta Pastor, I. (2011). Sociología de las Organizaciones. Madrid: Editorial Universitas.

Buró, R.S. eta Ronchi, D. (1990). Contested control in a large manufacturing plant. En Weesie, J. eta Flap, H. (eds.), Social networks through time (pp. 121-157). Utrecht: ISOR.

Burt, R.S. eta Talmud, I. (1993). Market niche. Social Networks, n. ${ }^{15}$, pp. 133-149.

Castells, M. (2009). Comunicación y poder. Madrid: Alianza Editorial.

Christakis, N.A. eta Fowler, J.H. (2010). Conectados. Madrid: Taurus.

Csaba, Z.L. eta Pál, J. (2010). How negative networks are forming and changing in time? Theoretical overview and empirical analysis in two high-school classes. Review of sociology, vol. 20, n. ${ }^{\circ}$, pp. 69-95.

DiMaggio, P.J. eta Powell, W. (1983). The iron cage revisited: institutional isomorphism and collective rationality in organizational fields. American Sociological Review, n. ${ }^{\circ} 48$, pp. 147-160. 
Dueñas-Cid, D. (2015). El Camp d’Acció Estratègic Vë̈nal de la ciutat de Tarragona: Organitzacions, Lideratges i Xarxes (Tesis Doctoral). Tarragona: Universitat Rovira i Virgili.

Fligstein, N. (2011). Towards a General Theory of Strategic Action Fields. Sociological Theory, vol. 29, n. ${ }^{0}$ 1, pp. 1-26. DOI: https://doi.org/10.1111/j.1467-9558.2010.01385.x

Flores, R., Koster, M., Lindler, I. eta Molina, E. (2012). Networks and collective action. Social Networks, vol. 34, n. ${ }^{\circ}$ 4, pp. 570-584. DOI: https://doi.org/10.1016/j.socnet.2012.06.003

Giner, S. (2002). Diccionario de Sociología. Madrid: Alianza Editorial.

Granovetter, M. (1973). The strength of weak ties. American journal of sociology, vol. 78, n. ${ }^{\circ}$, pp. 1360-1380.

Haider, F. (1958). The psychology of interpersonal relations. New York: Wiley.

Ibarra, H. (1992). Homophily and differential returns: sex differences in network structure and access in an advertising firm. Administrative science quarterly, vol. 37, pp. 422447.

Ibarra, H. (1993). Personal networks of women and minorities in management: a conceptual framework. Academy of management review, vol. 18, pp. 56-87.

Juris, J.S. (2008). Networking Futures, the Movements against Corporate Globalization. Durham: Duke University Press.

Kahler, M. (2017). Networked Politics: Agency, Power and Governance. New York: Cornell University Press.

Kearns, M., Suri, S. eta Monfort, N. (2003). An experimental Study of the Coloring Problem on Human Subject Networks. Science, vol. 313, n. ${ }^{\circ}$ 5788, pp. 824-827. DOI: 10.1126/ science. 1127207

Labianca, G., Brass, D. eta Gray, B. (1998). Social networks and perceptions of intergroup conflict: The role of negative relationship and third parties. The Academy of Management Journal, vol. 41, n. ${ }^{\circ}$, pp. 55-67. DOI: https://doi.org/10.5465/256897

Lazega, E. (1992). Analyse de réseaux d'une organisation collégiale: les avocats d'affaires. Revue française de sociologie, vol. 33, n. ${ }^{4}$, pp. 559-589.

Lazega, E. (1994). Analyse de réseaux et sociologie des organisations. Revue française de Sociologie, vol. 35, n. ${ }^{\circ}$ 2, pp. 293-320. 
Lubbers, M.J. (2003). Group composition and network structure in school classes: a multilevel application of the $p^{*}$ model. Social Networks, vol. 25, pp. 309-332.

Lubbers, M.J. eta Snijders, T.A.B. (2007). A comparison of various approaches to the exponential random graph model: A reanalysis of 102 student networks in school classes. Social Networks, vol. 29, n. ${ }^{\circ}$, pp. 489-507.

Meyer, J. eta Rowan, B. (1991). Institutionalized Organizations: Formal Structure as Myth and Ceremony. En Powell, W. eta DiMaggio, P. (eds.), The New Institutionalism in Organizational Analysis’ (pp. 1-41). Chicago: University of Chicago Press.

Mitchell, J.C. (1969). Social Network in Urban Situations. Manchester: Manchester University Press.

Molina, J.L. (2001). El análisis de redes sociales: Una introducción. Barcelona: Ediciones Bellaterra.

Monge, P.R. eta Eisenberg, R.M. (1987). Emergent communication networks. En Jablin, F.M., Putnam, L.L, Roberts, K.H. eta Porter, L.W. (eds.), Handbook of organizational communication: an interdisciplinary perspective (pp. 304-342). Beverly Hills: Sage.

Nelly, M. eta O'Grada, C. (2000). Market Contagion: Evidence from the Panics of 1854 and 1857. American Economic Review, n. ${ }^{\circ}$ 90, pp. 1110-1124. DOI: 10.1257/aer.90.5.1110

Newcomb, T. (1961). The acquaintance process. New York: Richard \& Winston.

Olivier, A. eta Montgomery, K. (2005). Toward the construction of a profession's boundaries: Creating a networking agenda. Human Relations, vol. 58, n 9, pp. 1167-1184. DOI: https://doi.org/10.1177/0018726705058913

Powell, W. eta Oberg, A. (2017). Networks and Institutions. En Greenwood, R., Oliver, C., Lawrence, T. eta Meyer, R. (eds.). The SAGE Handbook of Organizational Institutionalism (pp. 446-476). London: SAGE. DOI: http://dx.doi.org/10.4135/9781526415066

Putnam, R. (1995). Bowling alone, America's declining social capital. Journal of Democracy, vol. 6, n. ${ }^{\circ}$, pp. 65-78. DOI: 10.1007/978-1-349-62397-6_12

Stevenson, W.B. (1990). Formal structure and networks of interaction within organizations. Social Science Research, n. ${ }^{\circ}$ 19, pp. 113-131.

Stevenson, W.B. eta Gilly, M. (1991). International design and emergent structure: information floor through organizational procedures and networks of ties within organizations. Comunicación presentada en la Subelt XI: Conferencia Internacional Social Networks, Florida. 
Stokman, F.N., Zizgler, R. eta Scott, J. (eds.) (1985). Networks of corporate power. Cambridge: Polity Press.

Stokman, F.N. eta Van Den Bos, J.M. (1992). A two-stage model of policy-making with an empirical test in the U.S. energy-policy domain. Research in Politics and Society, vol. 4, pp. 219-253.

Stokman, F.N. eta Van Oosten (1994). The exchange of voting positions: an object-oriented model of policy networks. En Bueno De Mesquita, B. eta Stokman, F.N. (eds.), European community decision making (pp. 105-127). New Haven: Yale University Press.

Takacs, K., Janky, B. eta Flache, A. (2008). Collective action and network change. Social Networks, vol. 30, n. ${ }^{\circ}$, pp. 177-189.

Urteaga, E. (2013). La teoría del capital social de Robert Putnam: originalidad y carencias. Reflexión Política, vol. 15, n. ${ }^{2}$ 29, pp. 44-60.

Uzzi, B. (1996). The Sources and Consequences of Embeddedness for the Economic Performance of Organizations: The Network Effect. American Sociological Review, vol. 61, pp. 674-678.

Uzzi, B. eta Spiro, J. (2005). Collaboration and Creativity: The Small World Problem. American Journal of Sociology, n. ${ }^{\circ} 111$, pp. 447-504.

Vermeij, L., Van Duijn, M.A. eta Baerveldt, CH. (2008). Ethnic segregation in context: Social discrimination among native Dutch pupils and their ethnic minority classmates. Social Networks, vol. 31, n. ${ }^{\circ}$, pp. 221-280.

Weesie, J. eta Flap, H. (1990). Social networks through time. Utrecht: ISOR. 